\title{
Doing Development with Men: Some Reflections on a Case Study from Mali
}

\section{Colette Harris*}

\begin{abstract}
1 Introduction
My interest in the issue of power started when I was studying Marx and his analyses of class-based power relations. However, I never felt that to look at class alone was satisfactory, especially in today's global context, where class has lost its organisational salience. Searching for a dimension of power where I could feel more personally involved, I found myself turning to gender-based power relations. This seemed not only to be a set of relations that directly touched my own life, since as a woman I belonged in the lower power position but deeper analysis convinced me that these form the fundament of all power relations.
\end{abstract}

This is not to refuse to acknowledge the force of oppression based on race, economic and educational status, ethnic background, religion, age, class and others, but rather to realise that all of these are differentially experienced according to one's sex. I do not mean to imply that oppression based on gender is stronger or more devastating than that based say, on race, but rather that we need to bear in mind that people's experiences of racism are gendered, that men and women are not regarded in the same way, nor treated the same, in any social group, oppressed or otherwise. Almost invariably, women find themselves in a lower position than men of their own social group and very often have to bear the brunt not just of their own but also of men's disenfranchisement taken out on them through violence.

Since it has usually been men who have had the power to articulate oppression, women's often very different experiences have largely been ignored and thus generally remain unacknowledged. This may help account for the fact that in civil rights and nationalist struggles, women's experiences tend to be subsumed to those of men, with the result that they may be expected to support their race or nationality on men's terms with their own oppression taking a back seat.

Both men and women are expected to live up to norms in the form of gender identities that circumscribe the behaviour and self-presentation of each sex within their particular social group and which almost invariably give the upper power position to men. This applies as much to the West, where despite the struggles of the last few decades, gender-based power differences are still clearly visible, as to the South.

This notwithstanding, women are a great deal more powerful than the norms imply. However, their power is not acknowledged in public discourse and that puts limitations on their capacity to exercise it, as I shall argue below.

One of the reasons for the failure to achieve equality between the sexes is a continued refusal to engage with the issue of men as gendered beings rather than as representatives of some putative human norm. In the post-enlightenment world view, the West still holds up as ideal; this norm is seen as disembodied and rational and thus the opposite of the supposedly emotional female, firmly grounded in her body. Regarding men as embodiments of often highly emotional masculinity would destroy this conceptual framework and with it the entrenched notions that men are better fitted to be leaders in politics and business. This is, I believe, an important factor in the strong resistance to the idea of deconstructing the male in development theory and thus is one reason why development practice has avoided working with men as gendered, as opposed to normative, beings (see Scott 1995). 
In many of today's development strategies that focus on the most vulnerable, usually seen as women and/or children, men are seen as privileged and thus unfit for serious concern. If they are addressed at all in development projects this is usually as ungendered norms in their roles as heads of household or workers, but never like women as gendered beings, and rarely as those responsible for family-related issues such as birth control.

This may be partly because development theory does not connect men with families as it does women. While many countries have ministries of women and children or women and the family, nowhere is there a ministry of men, women and the family; the phrase fathers and children is rarely heard.

Moreover, today's community-level development paradigms tend to work through those in lower power positions - those whom Robert Chambers (this IDS Bulletin) refers to as lowers. With regard to their families, adult men fill a position of uppers. And thus, according to Chambers, they are less likely to be addressed as capable of changing power relations. Even work on violence against women has tended to address women only, excluding men. This perhaps accounts for the relatively small impact of so much development work. My own work with men has corroborated Chambers' theory that working with uppers on changing power relations can produce highly positive results (e.g. Harris 2006b).

In other writings, I address the issue of how men become vulnerable through attempting to live up to norms of masculinity (Harris 2004, 2005b, 2006a). Here, I discuss how directly addressing men as gendered beings can benefit the entire community. I do this through an analysis of a small development intervention I carried out in a Malian village. Working with the men enabled me in only a few hours to make an impact that a year later still resonated there. While this is unlikely to have made more than very small inroads into gendered power imbalances and the lack of ongoing contact almost certainly means that the long-term effect was limited, it nevertheless had a far greater impact than any I have been able to produce working with women alone.

This is no doubt, as Chambers (this IDS Bulletin) suggests, because changes in power relations are much easier to make with the collaboration of the more powerful - in this case men - and power shifts should be the main production of development interventions, dealing as they do with human relationships which are always linked to issues of power. Since the overt power in families resides with adult male heads of household, helping them deconstruct masculinity is one approach to producing power shifts and thus can be a potent development tool, as this article shows.

I start by describing the intervention, after which I set it within the context of masculinity and development and subsequently analyse power relations both within the village and between the community members and the various development actors involved.

\section{Family relations in a Malian village}

It is November 2001 and I have come to Mali on behalf of the Integrated Pest Management Collaborative Research Support Program's (IPM CRSP) project in partnership with the Malian governmental Institut d'Economie Rurale (IER). This project is being carried out in a number of villages just south of the capital, Bamako, teaching agricultural skills to farmers.

The villagers are all Muslims and most men have two or more wives living in the same homestead. While couples in monogamous unions might pool their income and use it for the family as a whole, women in polygynous unions tend to handle their own money, not to put it into a family pot, since they are unwilling to allow their co-wives and the latter's children to share with them (Harris 2005a). Such women supply a large part of their children's economic needs, with husbands who can afford it contributing cereals, medical expenses and sometimes school fees.

My intention was to carry out gender training exercises with both men and women in separate groups in the village of Mororo, which I visited along with a group of Malian IPM CRSP collaborators. ${ }^{2}$ We started by asking each group to compile a list of what they considered their most pressing problems. For both sexes, the majority of issues revolved around poverty, not only of individuals but of the village as a whole. Apparently there were only two men in the village able to earn sufficient to support their families and this meant that only two families out of 100 were able to meet their basic needs.

Traditionally, they all said, the men were expected to give their wives money to buy food. The older men had been able to do this reasonably well in their youth and still saw this as a norm they were expected 
to live up to. The younger men, however, had not even considered doing so. Since they were unable to provide the entire sum, they had chosen not to give their wives anything at all and simply expected them somehow to find enough supplies to feed their families. The women in fact all had earnings of their own, which in the absence of sufficient contributions from their husbands, they were forced to use for food. This was never enough so that they all had to be more careful about eating than in the past. This also meant that the women often could not afford to send their children to school. Many did not even have adequate clothes or shoes to do so.

The problem was in part due to lower agricultural productivity caused by drought, pests and illnesses and dwindling soil fertility. The farmers had no resources to buy fertiliser to compensate. In fact, they had problems even to find enough seed to plant each year and since they had no way of getting their produce to market, were usually forced to sell it at low prices to middlemen.

Another problem cited by both sexes was the workload of the village women. They carried out domestic tasks, were responsible for providing water and cooking fuel, helped their husbands farm and frequently farmed their own separate fields too. The men claimed not to be able to help the women, even with non-domestic tasks such as cutting and carrying wood, since these had always been considered women's work. They did help their wives a little by preparing and fertilising their fields but that was the extent of it. They certainly did not make any contribution to household labour. The men said that it was out of the question to help with such tasks. If one of their wives was away from home or sick, they would find another woman - a co-wife, sister or mother, to do the work if their daughters were too young.

The women further complained about their husbands' lack of ability to meet their children's needs. One woman said there were no more than five families in the village where men were capable of paying all their children's costs. In the rest of the families men's contributions varied from the majority of the costs down to nothing at all, while even at the worst times women somehow managed to find enough food to prevent the family dying of starvation. This also contributed to their exhaustion as they had to work exceedingly hard in order to find enough cash to buy food. One way of doing this was to go into the forest, cut down a tree and sell the wood. It was very hard work to get enough for cooking as well as for selling but without any education or marketable skills they had few alternatives.

In addition to their daily labours the women blamed constant childbearing for their exhaustion. Their husbands, they maintained, were absolutely against any type of family planning and wanted as many children as possible. One woman said she thought they would have 50 if this were possible. She had had three pairs of twins and was fed up with childbearing. At the very least she wanted a few years' rest before having any more. This woman, together with a few of her friends, begged me to discuss this with their husbands, saying she thought the men might listen to me even though they would not listen to them.

With some trepidation, I agreed to speak with the men. Sitting down with about ten of them, aged between about 20 and 45, who had assembled in a neighbouring courtyard, I broached the subject by asking how many children they wanted. The men shuffled around looking uncomfortable. After a few minutes, one of them, whom I will call Cheick, spoke up. He looked to be in his mid- to late-thirties and was the most articulate. He asked me how many children I thought they should have. I told them that I did not think it was any of my business. The decision was up to the families themselves. If they wanted 100 children each, that was fine by me. However, I was interested to know what kinds of plans they made in regard to the support of each successive child.

There was a shocked silence. What did she mean, 100 children, I could almost see them thinking. Cheick rather carefully enquired what I was talking about. I asked them to consider what a child might need once it had been brought into the world. They hesitatingly listed food, clothes, medicines, and one of them added schooling. Did they all have plenty of resources to do this, I wanted to know? This brought an instant reaction. No, they did not. They absolutely did not have enough resources, not at all. They could barely feed them. Clothing was a luxury (as I could see for myself, many of the children and even some of the men wore little better than rags) and school was out of the question for most of the children. $A$ serious illness could be a complete disaster.

The conversation moved on to other topics. Cheick, however, was no longer participating. He sat there 
apparently deep in thought for over half an hour. Then, just as the session was winding down, he spoke up. He informed us that he had always planned on having 15 children. He did not mean to put such a burden on one wife but rather planned to have five children each with three different women because he thought it was bad for one woman to have more than five. So far he had only one wife, with whom he already had five children, and he was contemplating taking a second. When he was a child he said, men did not have to think about family size. Everyone had large families and all members contributed their share of food. There was always plenty of this, as there had been in his grandfather's compound where he grew up. His father was one of 15 children and all the sons had helped support their parents, so that his grandparents had had an easy old age. This was his dream and he had thought to achieve it by having the same number of children.

In the past, said Cheick, small families were rarely prosperous. Large numbers of children were necessary to help with the labour. He had taken this for granted. However, my questions had started him considering the present situation.

When he was a boy the village was small. By 2001, the number of inhabitants was much larger and rapidly increasing. Thinking it over, he had realised with a shock that it no longer made economic sense for one man to have so many children. Before that day's discussion, he would have sworn the opposite, especially since personally he loved children. However my questions had started him thinking. He was poor, very poor. It was a struggle to support the children he already had on his small share of land. With two more wives and their children, he would actually be poorer, not richer as he had previously assumed. He had not considered the period between the children's birth and their being old enough to support him but now he realised this was crucial. He would need to support them for years before they would be able to support him, if indeed they ever could.

Cheick finished his statement by declaring vehemently that polygyny was a mistake. 'We men,' he said, 'need to rethink the way we live. We should start by abolishing polygyny.' He continued by saying that in today's large families there were always some children with health problems. It would be better to have fewer but healthier children. He was now determined, he said, to stick to his one wife and not have any more children. Just then the women came along, so the men's session ended there.

I returned to Mororo in the summer of 2002. I first met with the women and asked what had happened since my last visit. Were there any changes? They told me there was less illness in the village since we had talked about the relationship between hygiene and disease. For one thing, they had decided it was important to keep the village clean and so every Friday, the women would get together and sweep the public areas. They also said their relations with their husbands had improved. However, they did not know whether their husbands had changed their attitudes towards birth control because this was not a subject easily discussed.

Only a few of the men from the previous occasion were available but Cheick and several of his friends came to talk to us. Cheick in particular was enthusiastic at seeing me again. He told me that ever since my previous visit, family size and birth control had become important topics in the men's nightly discussions in the mosque, along with an argument over which was preferable - polygyny or monogamy. In fact, my visit had acted almost like a bomb, he said. In other words, it had been a significant catalyst for opinion change. When asked to explain, he told us the following. Over the previous five years, several non-governmental organisations (NGOs) had come to talk about family planning. The sessions had been like lectures and the men were made to look stupid and inferior because of their lack of technical knowledge and they were treated as if they automatically opposed the use of contraceptives. Because this offended them they had paid little attention.

Then one day we arrived. In the first place we treated them as human beings. We sat next to them on their benches. Furthermore, we neither told them what to do nor talked down to them. Rather, my questions had encouraged them to think and reflect for themselves. Afterwards, the group had described our conversation to their comrades in the mosque, and they had been so interested that the issues still formed an important topic of conversation.

Cheick had neither married again nor had another child and several other men also said they were now using contraception. Another outcome had apparently been that the men had started to talk 
more with their wives about important matters and to include them in decision making, something hitherto unheard of. Moreover, they claimed also to consider their wives' welfare more in regard to other issues, such as granting them a plot for themselves on the family land if they wanted. They had also reduced the amount of work they expected their wives to carry out on family land since, they said, men could increase their agricultural labour without risking a charge of effeminacy, which they could not do with other types of work. The overall result had been greater dialogue between spouses, enhanced family relations and improved health for the women.

\section{Men in development?}

The issue of whether and how to include men in development projects has recently started to receive considerable attention from researchers on gender and development (e.g. Cleaver 2002; Sweetman 2001a). Among the concerns raised is whether focusing on men is not simply a return to privileging them (Wassef 2001) and how far targeting men in development projects removes scarce resources from women-centred projects (Sweetman 2001b).

For a long time, men were viewed by those in gender and development as the problem. They were the ones holding women down, disempowering them, beating them up and/or infecting them with HIV. More recently, however, the study of men and masculinities has allowed development theorists and practitioners to acknowledge it is time to see men as also often disadvantaged and to consider how they might form part of the solution and not only of the problem. What such development might look like has recently been under discussion (e.g. Greig et al. 2000). A number of initiatives have brought men into development (e.g. Kandirikirira 2002) but there is still a long way to go in working out systematic theoretical and practical approaches.

Gender analysis has consisted to a large extent of considering the institutions and cultural practices that keep women in a structurally inferior position to members of the other sex with a view to seeing how these can be transformed to produce greater equity. This has tended to produce considerable resistance among men, who feel threatened with losing their power positions (Bhasin 2001).

Working with men on the difficulties they experience in performing masculinity may seem like a way of appealing to their self interest and reinforcing unequal gendered power relations, rather than using the opportunity to challenge their power over women (Bujra and Baylies 2001). However, the ways men often feel obliged to conceptualise and perform masculinity make it difficult for them to behave in ways that are empowering for women or even in ways that would seem to be useful for men themselves.

It has been demonstrated over and over, that masculinity is constructed in apposition to femininity. The masculine is viewed as powerful, strong and superior. Men should be virile, breadwinners, conquerors both of women and when necessary other men (Barker 2005; Connell 1996). Masculinity only exists in relation to a ritualised inferior femininity (Harris 2004; 2006a) and demands ways of keeping this femininity under control (Wassef 2001). In other words, it is fear of emasculation that is responsible for a great deal of men's behaviour in regard to domestic violence, multiple sex partners and other risky behaviour, such as the refusal to use condoms.

Development discourse has moved beyond the idea that men always use their superior power position to the detriment of their womenfolk. It is now admitted that even in the most disadvantaged communities, some men seek other ways of living (Barker 2005). There are many more who do not intentionally use the power they have been granted but who, because of the cultural patterns they were raised in, have never thought about other ways of behaving. It has simply not occurred to them to take into account the feelings and desires of their wives, daughters, or even sons.

Thus, Cheick and his friends were not all deliberate and nasty oppressors. They had simply not been raised to consider women's needs. Moreover, they had automatically followed the customs of their forefathers without thinking about the effects of recent political, economic and ecological changes.

Take the issue of polygyny raised by Cheick. In rural Mali, as in many other African settings, polygynous marriage enhances men's status. It implies both a superior power position vis-à-vis their wives and the financial ability to maintain several women and their children. As Cheick suggests, this institution is tied to the concept that large families are the most prosperous, something that applied when there was 
plenty of land and those with the largest families were best situated to take advantage of this. Today all the land belonging to Mororo has been allocated. ${ }^{3}$ Families have to make do with a much smaller plot than before and often cannot farm all of it for lack of water. Rather than too much land for a small family to farm, there is now too little productive land to feed a large one. The result is that while a man might be able to pay for the expenses of marrying a second wife, in the long term, the likelihood is that this will make the family worse off than before (Harris 2005a).

Cheick's idea that it was a good idea in today's circumstances to stick to monogamy was revolutionary since it would entail redefining masculinity. This may appear to make sense, since what he proposes could be regarded as constructing a form of masculinity more congruent with the current situation. However, since this will mean redefining how men achieve status in such rural settings where they have little else to base it on, it may not be so easy for most to accept.

The impetus for Cheick's thought processes that led to his proposing monogamy was the questions raised in our discussion. Had I or anyone else suggested that monogamy would be a rational response to their current difficulties, I have little doubt that Cheick along with his fellow villagers, would have summarily rejected the idea. It was because he came to this conclusion on his own that he saw it as logical and accepted it as meaningful for him and his friends. ${ }^{4}$

Moreover, Cheick and the others had been brought for the first time to consider consciously what it meant to be men in their particular situation and how as men, they could change their relationships with their womenfolk. The idea of a group of uneducated Muslim village men working through concepts of masculinity and going on to use these voluntarily to empower their own wives, to however slight a degree, is truly revolutionary and all the more so since we spent only a few hours in Mororo and provided very limited training. It was the men themselves who did the work. We had merely served as a catalyst.

\section{Power}

Multiple levels of power relations emerge from this story - between the women in the village and their menfolk and between the community and the various development agents who had visited the village, including of course myself and my partners.

The relationship between the development agents and the local population appeared to be extremely hierarchical, with the NGOs apparently taking it for granted that they had a right to enter a village and lecture their 'inferiors'. ${ }^{5}$ Cheick and his friends felt strongly that they were being condescended to. They felt unable to challenge the NGOs directly, since their higher power position was too silencing, but used their 'weapons of the weak' (Scott 1985) to do so indirectly by taking minimal notice of what they told them and expressing their resentment behind the backs of these outsiders. Moreover, their very refusal to conform to the behaviour changes the $\mathrm{NGO}$ staff wished to impose upon them was a way of tacitly refusing to accept the relations of power over them they were unable to refuse explicitly.

In the case of my own visit to Mororo, I went as part of a project that had been working in the villages for some time and was accompanied by IER agents that is by government researchers - working on the project. Several of the IER women insisted on wearing their best clothes and eating separately from the villagers. Unlike the village women, they would sit on chairs and, although apparently friendly, clearly distanced themselves from the community. They were visibly shocked when I sat on the mats with the women or on the benches side by side with the men. It was impossible to bring them to admit the importance of acknowledging the structural power differentials between themselves and the villagers, especially the village women, and explicitly trying to break down the barriers these caused.

Of course, my sitting together with the villagers, as also my deliberate choice of clothes similar in style and quality to theirs, could not obviate the fact of my positioning as an educated white woman, from the viewpoint of the inhabitants of Mororo unimaginably wealthy and equally unimaginably unconstrained by the kinds of social control they are constantly subject to, at community/family level as well as from the government. My conscious attempt both to acknowledge this gulf and to negate it, allowed me to establish a warm relationship with the villagers, so that they showed a certain level of acceptance.

However, it should also be said that it was easy for me to acknowledge and deliberately try to minimise the power differentials precisely because of the size 
of the gulf, which meant that I was in no way threatened by doing so, and that my acknowledging it could only permit me partially to overcome even those barriers I was aware of. Of course there must have been many which I was blind to.

I do not intend to imply that my personal relations with the community were the main reason for their responsiveness to our intervention. This, I believe, was the result of our transformative learning approach (see Harris 2006b). Nevertheless, the fact that Cheick was able to articulate my attitude towards him and his friends as contributory to the success of our intervention shows that it had in itself made a real impact, however illusory my attempt at producing an appearance of equality may have been.

Moreover, the very fact that I came from a so-called modern society as opposed to their traditionally minded one, was in itself a kind of hierarchy, given the attitude 'modern equals superior' that coexists in Mali alongside the rejection of much of what modernity stands for.

Thus, it could also be said that there are symbolic power relations between the new ideas encapsulated in the discourse of family planning that is, a discourse that arises out of modernity - and the more traditional ideas espoused by the older generation of villagers, such as Cheick's grandparents. A struggle for supremacy is being played out between these different worldviews in a setting where little of the modern can be seen. Surface appearances at least would suggest that there had been little change for decades, if not centuries. Nevertheless, the very fact that family planning is a familiar concept to all present indicates direct contact with institutions of modernity, and the willingness to consider using it points to the inevitable socioeconomic changes that the modernising force of globalisation has produced in Mororo.

The gendered power relations that give men the say in deciding whether or not a couple should use birth control are a way of maintaining social order by inculcating certain ways of doing and being from birth. This is a kind of disciplining of the body, similar but not identical, to what Foucault (1979) is talking about in his discussion of European disciplinary institutions or what Haugaard terms creating tacit knowledge through motions of predictability
(2003: 106). Thus, female and male bodies are expected from childhood to differ in the kinds of movements they make, the way they occupy space and express emotions, and the tasks they are trained to carry out as a matter of routine. Gender is thus not simply a black box of power differentials but contains a rich conglomeration of characteristics and roles assigned to one or the other sex within a specific social group.

An important issue within all these power relationships is the fact that the superior power position is conferred upon the holders by the community as a result of traditional methods of maintaining social order. It is not intrinsic to the people concerned (Haugaard 2003: 92). Thus, men's power over women is not directly, or indeed mainly, due to biology - that is, their ability to use physical force either on behalf of, or for controlling, their womenfolk - but rather part of the social order, accepted and thus confirmed by all concerned. It is this that gives men power over their wives. ${ }^{6}$

Mali is a gerontocratic society. This means that in effect older women gain power by virtue of their age. This grants them control over their daughtersin-law so that, although nobody in Mororo specifically mentioned it, it is not only husbands but also mothers-in-law who exercise control over young women and their fertility. Moreover, mothers have power over even adult sons.

Here we have a power relationship that is tacitly confirmed by society but which actually contravenes the discursively explicit gender relationships in which men are supposed always to have power over women. Public discourse on gender in gerontocratic communities is silent on the fact that this power is in fact given to older men over younger women and not to all men over all women. In other words, in Mali, the power of gerontocracy is greater than that of gender in certain ways but this is not usually articulated because men claim the upper hand in relation to gender, even though their power is mainly reduced to that over wives and daughters, both of whom are usually younger than themselves. Discursively, for instance, a woman cannot be a head of household, which again obscures the fact that a widow may have power over her adult son, since she is not supposed to be able to maintain a household without an adult male as at least a nominal head (see Harris 2004). 
The silence of discourse on the issue of women's power over younger men is similar to the concept of tacit or practical power relations discussed by Haugaard (2003: 100) - power relations that serve social order but which are not expressed discursively. However, it should also be noted that this silence serves to undermine women's power, thus rendering them less dangerous as power holders than they might otherwise be. In other words, it tends to weaken the 'power to' that women develop as they age within a traditional context as mothers of sons residing within their marital family, while leaving the more problematic 'power over' in place.

Simultaneously, it places younger men in a difficult situation. According to public discourse, they are expected to act as dominant members of society but they are hampered in this by the constraints on their power vis-à-vis older women, particularly their mothers and even grandmothers, as well as in relation to older men. In order to feel powerful despite their youth, young men may seek other ways of exhibiting their masculinity and thereby displaying a kind of 'power to', for instance through the practice of violence in community conflict situations or in relation to their wives and/or children, or by engaging in sexual relations with multiple partners and without a condom, as a proof of superior strength. Such acts may be seen as defying women's power and perhaps also that of their fathers. It can also be observed in many societies that the less power men have outside the family (such as economic, educational, employment-based or political power), the more they feel inclined to exert it within the family circle.?

In other words, we need to move beyond merely observing that tacit power relations exist, to considering which power relations are tacit, which explicit and why. Haugaard (2003: 101) states that once there is a change from tacit to explicit, this allows actors to reject relations that are to their disadvantage. This of course has been the point of consciousness raising in civil rights' movements, including women's movements.

However, as Foucault (1990: 101-102) points out, another effect of making power relations discursively explicit may be to reify and even solidify them. In fact, this has happened around gender identities and relations in settings such as Mali, where the population has been exposed to outside pressures from (neo)colonialism towards change and especially towards the 'emancipation' of women. The articulating of traditional gender power relations that takes place here can be co-opted by local communities and these relations turned into a means of resistance, of refusal of change (cf. Harris 2004).

Thus, in Mali, as with most other Southern societies where I have worked, the population openly articulates, and in general supports, male superiority. They can also list many significant components of male and female roles, as they did in Mororo when we looked at gender-specific tasks. They maintain silence, however, on anything that appears to present women in a higher and men in a lower position, such as the gerontocratic positioning discussed above.

Such positioning tends to remain invisible even in most social science representations of gender issues, perhaps because the study of gender relations emanated from a northern European/US perspective - that is from non-gerontocratic societies - and this has established a framework of binary power relations between the sexes that continues to influence research and conceptualisation on these questions. Despite a recent growth in emphasis on masculinities' studies, the overwhelming majority of gender work continues to concentrate on the fight for female equality. The multiplicity and complexity of gendered power relations tends therefore to be ignored. So too does Foucault's concept of the micro-mechanisms of power and the way this circulates through society, each pressure point meeting with a certain level of resistance (1980: 94-6), often through the use of Scott's weapons of the weak (1985).

The implications here are that women at all social levels have multiple ways to express rebellion, resistance, and/or subversion and in fact often those who do so may benefit more than those who conform but once this becomes explicit rather than remaining tacit, the likelihood of backlashes increases (see Harris 2004).

\section{Conclusion}

Power relations in such a setting as this one in Mali are multiple and complex and exist in more dimensions than we usually consider. They also circulate in the Foucauldian manner with all pressures meeting with some manner and strength of resistance, and combine the tacit and the explicit. 
In my work in Mororo, I was able to use deliberate tactics in order to encourage the development of a different kind of male power than that which is established through gender relations, a kind of

\section{Notes}

* I would like to thank Jethro Pettit and Rosalind Eyben for their comments on an earlier version of this article.

1 I want to thank Haoua Sissoko, Issa Sidibé, Ma Koné and Abdoulaye Camara for their help with the training in these villages, as well as Kadiatou Gamby, Mali site coordinator, for facilitating the work. The Integrated Pest Management Collaborative Research Support Program (IPM (RSP) is funded by the United States Agency for International Development (USAID).

2 Not its real name. I have concealed the identity of the village to protect the privacy of its inhabitants, whose names I have also changed.

3 In Mali, individuals do not own land. Each village has its own area, which the chief divides among the families living there

4 The methodology that we used to support the men to work this through for themselves has been called transformative learning. I describe it at length in Harris (2006b).

\section{References}

Barker, Gary T. (2005) Dying to be Men: Youth, Masculinity and Social Exclusion, London: Routledge

Bhasin, Kamla (2001) 'Gender Training with Men: Experiences and Reflections from South Asia', in Caroline Sweetman (ed.), Men's Involvement in Gender and Development Policy and Practice: Beyond Rhetoric, Oxford: Oxfam

Bujra, Janet and Baylies, Carolyn (2001) Targeting Men for a Change, ID21 Research Highlights, www.id21.org (accessed July 2006)

Cleaver, Frances (2002) Masculinities Matter: Men, Gender and Development, London: Zed Books

Connell, Robert (1996) Masculinities, Cambridge: Polity Press

Foucault, Michel (1990) The History of Sexuality, Vol. 1 An Introduction, London: Penguin Books

Foucault, Michel (1980) Power/Knowledge, C. Gordon (ed.), Hemel Hempstead: Harvester Wheatsheaf

Foucault, Michel (1979) Discipline and Punish, New York: Vintage Books power that increases men's capacity for power 'within' and 'to', and is intended to reduce their desire for power 'over'.

5 I do not mean to suggest that all Malian NGOs work in a hierarchical and insensitive manner. Indeed, I have been involved with NGOs that work in a highly sensitive and inclusive way and which in part because of this have success. However, according to Cheick and his friends, the NGOs they had encountered were not of this type.

6 According to this theory, it would be much harder for men to use physical violence to control their female partners if both sides acknowledged that this was completely out of order and inappropriate, despite the physical inequalities that would still exist and that make it easier for men to beat their wives than the other way around. After all, the most powerful men in society are not the physically strongest.

7 But, of course, rich and seemingly powerful men are also perpetrators of the worst kinds of domestic violence, perhaps because they do not experience themselves as powerful, despite their positionality.

Greig, Alan, Kimmel, Michael and Lang, James (2000) Men, Masculinities and Development: Broadening our Work towards Gender Equality, Gender in Development Monograph Series 10, New York: United Nations Development Programme (UNDP)

Harris, Colette (2006a) Muslim Youth: Tensions and Transitions in Tajikistan, Boulder, CO: Westview Press

Harris, Colette (2006b) Transformative Education for Development: A Journey of Personal Exploration, IDS Working Paper (forthcoming)

Harris, Colette (2005a) 'How Deconstructing Gender Identities Could Contribute to the Solution of Difficult Development Problems: Case Studies on Poverty and the Transmission of HIV/AIDS', in Consolata Kabonesa (ed.), Constructing and Deconstructing Gender Identities: Cross Cultural Dynamics, Kampala: Fountain Publishers

Harris, Colette (2005b) 'Tackling Sexual Distress: Two Case Studies from the Central Asian Republic of Tajikistan', in Diana Gibson and Anita Hardon (eds), Rethinking Masculinities, Violence and AIDS, Amsterdam: Het Spinhuis: 175-200 
Harris, Colette (2004) Control and Subversion: Gender Relations in Tajikistan, London: Pluto Press

Haugaard, Mark (2003) 'Reflections on Seven Ways of Creating Power', European Journal of Social Theory 6.1: 87-113

Kandirikirira, Niki (2002) 'Deconstructing Domination: Gender Disempowerment and the Legacy of Colonialism and Apartheid in Omaheke, Namibia', in Frances Cleaver (ed.), Masculinities Matter: Men, Gender and Development, London: Zed Books: 112-37

Scott, Catherine (1995) Gender and Development: Rethinking Modernization and Dependency Theory, Boulder: Lynne Rienner Publishers

Scott, James (1985) Weapons of the Weak: Everyday Forms of Peasant Resistance, New Haven: Yale University Press
Sweetman, Caroline (2001a) Men's Involvement in Gender and Development Policy and Practice: Beyond Rhetoric, Oxford: Oxfam

Sweetman, Caroline (2001b) "'Sitting on a Rock": Men, Socio-economic Change, and Development Policy in Lesotho', in Caroline Sweetman (ed.), Men's Involvement in Gender and Development Policy and Practice: Beyond Rhetoric, Oxford: Oxfam Wassef, Nadia (2001) 'Male Involvement in Perpetuating and Challenging the Practice of Female Genital Mutilation in Egypt', in Caroline Sweetman (ed.), Men's Involvement in Gender and Development Policy and Practice: Beyond Rhetoric, Oxford: Oxfam 